\title{
Integration of CompTIA Cloud+ into Universiti Teknologi MARA's Computer Engineering Special Topics Syllabus
}

\author{
Ihsan Mohd Yassin ${ }^{\# \&}$, Md Mahdfudz Md Zan ${ }^{\#}$, Nooritawati Md Tahir", Husna Zainol Abidin", Zairi \\ Ismael Rizman* \\ ${ }^{\#}$ Faculty of Electrical Engineering, Universiti Teknologi MARA, 40450 Shah Alam, Selangor, Malaysia \\ ${ }^{\%}$ Malaysian Institute of Transport (MITRANS), Universiti Teknologi MARA, 40450 Shah Alam, Selangor, Malaysia \\ ${ }^{\star}$ Microwave Research Institute (MRI), Universiti Teknologi MARA, 40450 Shah Alam, Selangor, Malaysia \\ E-mail: ihsan.yassin@gmail.com,mahfudz@salam.uitm.edu.my,norita_tahir@yahoo.com,along_husna@yahoo.com \\ *Faculty of Electrical Engineering, Universiti Teknologi MARA, 23000 Dungun, Terengganu, Malaysia \\ E-mail: zairi576@tganu.uitm.edu.my
}

\begin{abstract}
Cloud computing is one of the frontier technologies in computer engineering. Therefore, it is important to prepare the students with the knowledge and skills required in this field. This paper describes the integration of the renowned CompTIA Cloud+ professional training course into the ECE648: Special Topics in Computer Networking subject. The subject is a final year elective for the Faculty of Electrical Engineering, Universiti Teknologi MARA, Malaysia undergraduate computer engineering students. We first begin by assessing the current teaching syllabus of a variety of international universities to establish fundamental topics that should be covered in a cloud computing course. We then proceed to describe our implementation, which is done in accordance with the CompTIA Cloud+ certification syllabus. Among the items described are how the Cloud+ course contents are adjusted to be more suitable for the course, as well as additional practical elements (not originally available in the Cloud+ course) added to the course syllabus. Implementation results are described.
\end{abstract}

Keywords - cloud computing; computer engineering; engineering education; CompTIA Cloud+

\section{INTRODUCTION}

Cloud computing is a model for enabling ubiquitous, convenient, on-demand access to a shared pool of configurable computing resources [1]. Cloud computing and storage solutions provide users and enterprises with various capabilities to store and process their data in third-party data centers [2]. It relies on sharing of resources to achieve coherence and economies of scale over a network [1]. According to the report by an independent consulting company, IDC, the demand for cloud professionals would reach 22 million people by the year 2020 with a projected annual growth demand of $26 \%$ per year. In terms of cloud computing growth, in [3] estimates that by the year 2018, $78 \%$ of global computing workloads will be processed by datacenters in the cloud, while [4] estimates that the cloud computing market will reach a market size of USD 127 billion by 2017 .

It is important that computer engineering undergraduate students are prepared for this next wave of computing technology. In response to this, the Department of Computer Engineering, Universiti Teknologi MARA (UiTM) Malaysia has recently established the CompTIA Regional Academy in the Faculty of Electrical Engineering in collaboration with CompTIA to establish and expertise in this area. The Academy offers CompTIA Cloud+ certification for current and future professionals working in the area of cloud computing.

An opportunity to embed the Cloud+ curriculum into the current Bachelor in Electronics Engineering program exists in the form of Special Topics subjects. Special Topics subjects allow lecturers the freedom to define their own syllabus based on the current trends in the industry.

This paper intends to share the implementation of embedding the Cloud+ curriculum into the current Special Topics syllabus. This project would benefit the students in preparing them for their future careers.

This paper is organized as follows: Section II presents a review of cloud computing subjects from several universities worldwide. This is followed by a description of the CompTIA Cloud+ professional certification and the ECE648 course. Implementation results are described in Section III. The recommended infrastructure requirements for implementation is also presented in Section III. Finally, concluding remarks are presented in Section IV. 


\section{MATERIAL AND METHOD}

\section{A. Cloud Computing Syllabus in Other Universities}

This section presents a review of the cloud computing syllabus for various universities worldwide. The depth ranges from introductory to advanced levels and they are primarily taught to either computer engineering or computer science students. The review is presented in Table 1.

TABLE I

SUMmaRy OF CLOUd COMPUTING SUBJECTS AT UNDERGRADUATE LEVEL FROM SEVERAL UNIVERSITIES WORLDWIDE

\begin{tabular}{|c|c|}
\hline & escription \\
\hline $\begin{array}{l}\text { 2626: } \\
\text { ating } \\
\text { arsity, } \\
\text { alia) [5] }\end{array}$ & $\begin{array}{l}\text { This subject is taught to Computer Science } \\
\text { and Information Technology students. The } \\
\text { topics cover resource management, } \\
\text { programming and application models, system } \\
\text { characterizations and implementations. The } \\
\text { course also covers the enterprise aspect of } \\
\text { cloud computing, exposing students to } \\
\text { several industry-grade cloud enterprises such } \\
\text { as Amazon EC2 and S3, Microsoft Azure, } \\
\text { Google AppEngine, Google's MapReduce, } \\
\text { Yahoo's Hadoop and others. }\end{array}$ \\
\hline $\begin{array}{l}\text { 42904: Cloud } \\
\text { Computing and } \\
\text { SaaS } \\
\text { (University of } \\
\text { Technology } \\
\text { Sydney, } \\
\text { Australia) [6] }\end{array}$ & $\begin{array}{l}\text { Subject introduces fundamentals of cloud } \\
\text { computing and their application to Software } \\
\text { as a Service (SaaS) cloud. Multi-tenancy and } \\
\text { virtualization features are also described. } \\
\text { Assessment is conducted in the form of } \\
\text { assignments, report, presentation and final } \\
\text { examination. Assessment primarily focuses } \\
\text { on written assignment and final examination. }\end{array}$ \\
\hline $\begin{array}{l}\text { 51: } \\
\text { uting } \\
\text { es Sturt } \\
\text { rsity, } \\
\text { lia) }\end{array}$ & $\begin{array}{l}\text { This subject covers several important aspects } \\
\text { of cloud computing technologies and their } \\
\text { applications in business. Among the areas } \\
\text { covered in the syllabus are: } \\
\text { - Fundamentals of Cloud Computing. } \\
\text { - Cloud Architectures. } \\
\text { - Cloud Delivery Models. } \\
\text { - Cloud Risk Management. } \\
\text { - Cloud Security. } \\
\text { - Planning a migration to the Cloud. } \\
\text { - Cloud Governance and Management. } \\
\text { - Managing the Cloud Infrastructure. }\end{array}$ \\
\hline $\begin{array}{l}\text { ing } \\
\text { sity } \\
\text { [7] }\end{array}$ & $\begin{array}{l}\text { This subject covers parallel computing, } \\
\text { distributed computing, distributed file } \\
\text { systems as an introduction to cloud } \\
\text { computing. Several service models are also } \\
\text { covered, namely Software as a Service } \\
\text { (SaaS), Infrastructure as a Service (IaaS) and } \\
\text { Platform as a Service (PaaS). It also covers } \\
\text { security and economics of cloud computing. } \\
\text { Additionally, several enterprise cloud } \\
\text { computing architectures are discussed. } \\
\text { Student evaluations are divided into practical } \\
\text { (assignments, practical work, and projects) } \\
\text { and written assignments (tests and final } \\
\text { examination). }\end{array}$ \\
\hline $\begin{array}{l}\mathrm{Bc} \\
\mathrm{C} \\
\mathrm{Sc} \\
\text { in } \\
\mathrm{C} \\
\mathrm{Te}\end{array}$ & $\begin{array}{l}\text { This Malaysian private education institution } \\
\text { is offering an undergraduate degree in cloud } \\
\text { computing technology. Comparing it to the } \\
\text { rest of the entries, it offers a comprehensive } \\
\text { set of subjects related to cloud computing. } \\
\text { From the study plan, the program first } \\
\text { addresses the fundamentals of computing in } \\
\text { its first year (Java, data communication, }\end{array}$ \\
\hline
\end{tabular}

University,

Malaysia) [8]

CEN 6086:

Cloud

Computing

(University of

North Florida,

USA) [9]

CS 526:

Enterprise and

Cloud

Computing

Syllabus

(Stevens

Institute of

Technology,

New Jersey,

USA) [10]

CS 643: Cloud

Computing

Syllabus (New

Jersey Institute

of Technology,

New Jersey,

USA) [11] database systems and fundamentals of computers and mathematics). In the second year, the study plan focuses on networking, wireless and mobile networks as well as distributed computing and advanced programming subjects. The final year focuses on network security, knowledge management, high-speed networks, cloud application development and enterprise storage systems.

This program appears to be the most comprehensive compared to the other entries (as it is a complete undergraduate course focused on cloud computing).

This graduate level course focuses on cloud computing models, techniques, and architectures. Course contents include distributed computing models and technologies, cloud delivery models, virtualization, security and privacy issues, performance and systems issues, capacity planning, disaster recovery, cloud operating systems, federated clouds, challenges in implementing clouds, data centers, hypervisor CPU and memory management, cloud hosted applications, and other advanced and research topics in cloud computing. Course evaluation is done using examinations, assignments, projects, as well as oral and poster presentations.

The CS 526 course focuses on large-scale enterprise computing, which also includes cloud computing as a mechanism to outsource the computing requirements of enterprises. The topics cover many cloud computing areas and tools, such as Amazon EC2, Windows Azure, MapReduce, NoSQL, cloud operating systems, and virtualization. In addition, the course also covers secure operating systems (Security Enhanced Linux), stream processing, data warehousing as well as databases, enterprise services and contracts, and security aspects of enterprise computing.

This course covers several aspects of cloud computing including the applications, administration, programming and cloud infrastructure. The chapters covered in this course include:

- Introduction to Cloud Computing

- Cloud Computing Platforms

- Parallel Programming in Cloud

- Distributed Storage Systems

- Virtualization

- Cloud Security

- Multicore Operating Systems

Student evaluations are divided into practical (programming assignments, and project), presentations and written assignments (test and final examination).

Cloud

Computing

Syllabus (Dept.

of Computer

Science,

National Tsing Hua
This undergraduate course presents an introduction to cloud computing, its techniques, and environment. The course contents include:

- Overview of Distributed Computing

- Introduction to Cloud Computing

- Cloud Delivery Models (Infrastructure 


\begin{tabular}{|l|l|}
\hline University, & as a Service (IaaS), Platform as a \\
Taiwan) [12] & $\begin{array}{l}\text { Service (PaaS), and Software as a } \\
\text { Service (SaaS). Covers virtualization } \\
\text { of resources, computation and storage } \\
\text { issues, and web-based services and } \\
\text { operating systems. } \\
\text { - Cloud Computing Issues and } \\
\text { Challenges. Covers security issues and } \\
\text { cloud service providers. } \\
\text { Assessment is done primarily through } \\
\text { laboratory sessions and term projects. } \\
\text { Quizzes and participation are also assessed. }\end{array}$ \\
\hline
\end{tabular}

Based on the review in Table 1, several key areas were considered when adapting the CompTIA Cloud+ syllabus into the ECE 648 course:

- Fundamentals of cloud computing.

- Cloud computing service models.

- Management and security of the cloud.

- Networking.

- Cloud computing storage.

- Knowledge of current enterprise cloud computing solutions (including virtualization).

\section{B. Description of CompTIA Cloud+ Traning Course}

Skills in cloud computing are becoming more demanding as an increasing number of businesses shift from traditional enterprise computing to cloud computing The CompTIA Cloud+ certification is a professional training course aimed to accredit practitioners in Information Technology (IT) responsible for implementation of maintenance of cloud computing technologies. The course covers essential broad areas in cloud computing namely [13]:

- Cloud models

- Virtualization

- Infrastructure

- Security

- Resource Management

- Business Continuity

After completing training, candidates are required to take a professional examination in order to be certified. The examination consists of 100 multiple-choice questions answerable over 90 minutes with a passing mark of 750/900 [13].

\section{Description of ECE648: Special Topics in Computer Networking}

The ECE648 course is offered as a final-year elective for computer engineering students enrolled the EE241: Bachelor of Engineering (Hons) Electronic Engineering program. The subject syllabus is flexible, which allows the course instructor to introduce new technologies and research areas related to computer networks.

The course credit hours are three (3 hours' lecture and 1hour laboratory tutorial per week). The student learning time is 122 hours, divided into 50 face-to-face hours and approximately 72 hours of student preparation time (selfstudy, preparation for tests and assignments, etc.).

Due to the flexible course syllabus, the objectives of the course are generic in nature and for the students to be able to:
- describe recent developments in computer networking.

- apply the main concepts of emerging technologies.

- implement the technology for real-world applications.

This allows any recent technologies and developments in the field of computer networking to be integrated into the syllabus with relative ease.

The subject is evaluated based on two tests, two assignments and one project. Each assignment carries $10 \%$ contribution to the marks, while the tests contribute $15 \%$ each. The final project carries the highest marks, which is $50 \%$.

A general overview of the methodology is presented in Fig. 1, and a description of each process is presented in the following sections.

\section{RESULTS AND DISCUSSION}

This section is divided into three sections. Section III-A describes the implementation of lecture, followed by the tutorial implementation (Section III-B). Finally, the final project implementation is described in Section III-C.

\section{A. Lectures}

Lectures are conducted in two classes per week. Typically, the teaching time for first class is two hours, and one hour for the second class. Tests and assignments are also conducted during class hours.

The lecture materials used in the classes are available at [14] for perusal. A summary of the chapters and lecture activities are presented in Table 2 .

TABLE III

LECTURE CHAPTERS AND DESCRIPTION

\begin{tabular}{|c|c|c|}
\hline Lecture & $\begin{array}{l}\text { Duration } \\
\text { (Weeks) }\end{array}$ & Description \\
\hline $\begin{array}{l}\text { L1: Cloud } \\
\text { Computing - } \\
\text { Concepts, } \\
\text { Models, and } \\
\text { Terminology }\end{array}$ & 1 & $\begin{array}{l}\text { This lecture covers the } \\
\text { fundamentals and key concepts of } \\
\text { cloud computing: } \\
\text { 1. Concept of Cloud Computing: } \\
\text { a. comparison between } \\
\text { traditional computing versus } \\
\text { cloud computing. } \\
\text { b. growth and motivations for } \\
\text { adoption. } \\
\text { 2. Cloud Service Models- } \\
\text { Infrastructure as a Service } \\
\text { (IaaS), Platform as a Service } \\
\text { (PaaS), Software as a Service } \\
\text { (SaaS) and other models. } \\
\text { 3. Cloud Delivery Models and } \\
\text { Services: Private, Public, } \\
\text { Hybrid and Community, On- } \\
\text { Premise vs. Off-Premise } \\
\text { Hosting Platforms: } \\
\text { 4. Orchestration that } \\
\text { Automated software the that } \\
\text { simplifies the management of } \\
\text { tasks for cloud users and } \\
\text { administrators. } \\
\text { 5. Cloud Characteristics and } \\
\text { Terms: Explores some } \\
\text { common terms commonly used } \\
\text { in Cloud Computing, such as }\end{array}$ \\
\hline
\end{tabular}




\begin{tabular}{|c|c|c|}
\hline & & $\begin{array}{l}\text { ubiquitous access, } \\
\text { multitenancy, bursting and pay } \\
\text { as you grow. }\end{array}$ \\
\hline $\begin{array}{l}\text { L2: Disk } \\
\text { Storage } \\
\text { Systems }\end{array}$ & 2 & $\begin{array}{l}\text { Explores storage devices and their } \\
\text { configuration in a cloud } \\
\text { computing environment. Among } \\
\text { the topics explored are: } \\
\text { 1. Disk types and configurations: } \\
\text { Hard Disk Drive (HDD), Solid } \\
\text { State Disk (SSD) and magnetic } \\
\text { tape. } \\
\text { 2. Storage interfaces: how the } \\
\text { storage devices are interfaced } \\
\text { with the cloud computing } \\
\text { hardware. } \\
\text { 3. Tiering: Method to improve } \\
\text { cloud computing response by } \\
\text { organizing the disks into } \\
\text { several groups depending on } \\
\text { their performance. } \\
\text { 4. Redundant Array } \\
\text { Independent Disks (RAID): A } \\
\text { strategy to combine storage } \\
\text { resources of several disks to } \\
\text { improve data security and read } \\
\text { and write performance. } \\
\text { 5. File systems: Explores several } \\
\text { filesystem types used in several } \\
\text { most popular operating } \\
\text { systems. }\end{array}$ \\
\hline $\begin{array}{l}\text { L3: Storage } \\
\text { Networking }\end{array}$ & 2 & $\begin{array}{l}\text { Explores several strategies to } \\
\text { configure the storage devices in } \\
\text { L2 for use in a cloud environment. } \\
\text { 1. Storage Technologies: Direct } \\
\text { Access Storage (DAS), } \\
\text { Network Access Storage } \\
\text { (NAS) and Storage Area } \\
\text { Network (SAN). } \\
\text { 2. Block Level vs. File Level } \\
\text { Storage: How the data is stored } \\
\text { on the disks and the level of } \\
\text { access (block level or file } \\
\text { level). } \\
\text { 3. Access Protocols: Protocols for } \\
\text { communication between the } \\
\text { disks and the cloud computing } \\
\text { environment. } \\
\text { 4. Logical Unit Number (LUN), } \\
\text { LUN Masking and } \\
\text { Multipathing: LUN and LUN } \\
\text { Masking describes how access } \\
\text { is controlled to a particular } \\
\text { volume in a SAN storage } \\
\text { solution. } \\
\text { describes how redundancies in } \\
\text { network connections are } \\
\text { established by allowing several } \\
\text { options on how data can be } \\
\text { transmitted across the network. }\end{array}$ \\
\hline $\begin{array}{l}\text { L4: Network } \\
\text { Infrastructure }\end{array}$ & 3 & $\begin{array}{l}\text { This chapter covers the following: } \\
\text { 1. Types of networks: Discusses } \\
\text { several network types such as } \\
\text { Intranet, Extranet, and the } \\
\text { Internet. } \\
\text { 2. Network Topologies: } \\
\text { Discusses several methods how } \\
\text { the nodes in the network can be } \\
\text { interconnected with one }\end{array}$ \\
\hline
\end{tabular}

\begin{tabular}{|c|c|c|}
\hline & & $\begin{array}{l}\text { another, as well as the pros and } \\
\text { cons for each configuration. } \\
\text { 3. Network Optimization: } \\
\text { Strategies to optimize the } \\
\text { response speed of the network. } \\
\text { Several strategies covered are } \\
\text { compression, caching and load } \\
\text { balancing. } \\
\text { 4. Routing \& Switching: Covers } \\
\text { the differences between a } \\
\text { router and switch in a network, } \\
\text { as well as how these devices } \\
\text { transmit data over the network } \\
\text { (Network Address Translation } \\
\text { (NAT) and Port Address } \\
\text { Translation (PAT)). Subnetting } \\
\text { and supernetting strategies to } \\
\text { group nodes in the network are } \\
\text { also covered. }\end{array}$ \\
\hline $\begin{array}{l}\text { L5: } \\
\text { Virtualization } \\
\text { Components }\end{array}$ & 2 & $\begin{array}{l}\text { Covers the fundamentals of } \\
\text { virtualization and how they are } \\
\text { used to maximize the utilization of } \\
\text { computing resources in a cloud. } \\
\text { This chapter also discusses the } \\
\text { host configuration strategy for } \\
\text { maximum virtualization efficiency } \\
\text { and performance. }\end{array}$ \\
\hline
\end{tabular}

*Remaining 4 weeks used for the final project.

\section{B. Tutorial (Laboratory Session)}

The laboratory works emphasize the skills necessary for the students to use and manage the cloud, as well as to strengthen the knowledge learned in class. The laboratory modules were created based on the lessons from CompTIA Cloud+ syllabus. The laboratory modules are shown in Table 3. All laboratory works are individually assessed.

TABLE IIIII

LABORATORY SESSION SCHEDULE AND DESCRIPTION

\begin{tabular}{|c|c|c|}
\hline Tutorial & $\begin{array}{l}\text { Duration } \\
\text { (Weeks) }\end{array}$ & Description \\
\hline $\begin{array}{l}\text { T1: Google } \\
\text { cloud } \\
\text { offerings }\end{array}$ & 2 & $\begin{array}{l}\text { In this laboratory session, students } \\
\text { are required to learn about several } \\
\text { cloud computing concepts through } \\
\text { Google "s cloud-based products. } \\
\text { The students are required to create } \\
\text { their own "company", utilize } \\
\text { Google Drive (Draw, Docs, Sheets, } \\
\text { Slides) and Google Sites to help } \\
\text { them start and manage the business. } \\
\text { The students are required to create } \\
\text { a company website using Google } \\
\text { Sites, embedding as many other } \\
\text { Google services such as YouTube } \\
\text { and Google Maps. } \\
\text { In the Google Drive cloud storage } \\
\text { system, students are expected to } \\
\text { learn how to manage the files, } \\
\text { utilize the embedded Google Draw } \\
\text { app to create the company logo, } \\
\text { utilize Google Docs to create } \\
\text { invoices and receipts. }\end{array}$ \\
\hline $\begin{array}{l}\text { T2: Berkeley } \\
\text { Open } \\
\text { Infrastructure } \\
\text { for Network } \\
\text { Computing }\end{array}$ & 1 & $\begin{array}{l}\text { This laboratory session will explore } \\
\text { BOINC, a distributed cloud } \\
\text { computing software that harnesses } \\
\text { the idle processing of computers } \\
\text { worldwide to perform various types }\end{array}$ \\
\hline
\end{tabular}




\begin{tabular}{|c|c|c|}
\hline (BOINC) & & $\begin{array}{l}\text { of computation for the benefit of } \\
\text { science. Students will learn how to } \\
\text { install and configure the BOINC } \\
\text { client and used it to contribute to a } \\
\text { project of their choosing. }\end{array}$ \\
\hline $\begin{array}{l}\text { T3:Database } \\
\text { as a Service } \\
\text { (DBaaS) }\end{array}$ & 2 & $\begin{array}{l}\text { This laboratory session teaches } \\
\text { students to create a web and } \\
\text { database server using Apache and } \\
\text { MySQL respectively. } \\
\text { The students will then learn how to } \\
\text { install and configure the web server } \\
\text { with its MySQL database service. } \\
\text { The students are then expected to } \\
\text { develop an online system to store } \\
\text { information about customer, } \\
\text { products and orders information } \\
\text { using PHP. }\end{array}$ \\
\hline T4: Storage & 1 & $\begin{array}{l}\text { In this laboratory session, the } \\
\text { students are expected to learn how } \\
\text { to install, configure and manage an } \\
\text { open-source cloud-based Network } \\
\text { Access Storage (NAS) system } \\
\text { called OwnCloud. This session } \\
\text { corresponds with Chapter T3 of the } \\
\text { syllabus. }\end{array}$ \\
\hline $\begin{array}{l}\text { T5: VMWare } \\
\text { Player }\end{array}$ & 2 & $\begin{array}{l}\text { This laboratory session teaches } \\
\text { students on how to install, } \\
\text { configure and manage a } \\
\text { virtualization software using a } \\
\text { type- } 2 \text { hypervisor called VMWare } \\
\text { Player. This tutorial can be moved } \\
\text { ahead of T2 if students are required } \\
\text { to implement the T2 and T3 on a } \\
\text { virtual machine. }\end{array}$ \\
\hline $\begin{array}{l}\text { T6: VMWare } \\
\text { ESXi \& } \\
\text { VMWare } \\
\text { vSphere } \\
\text { Client }\end{array}$ & 2 & $\begin{array}{l}\text { This session teaches students on } \\
\text { how to install, configure access and } \\
\text { manage an enterprise-level } \\
\text { virtualization software with the } \\
\text { type-2 hypervisor (VMWare ESXi) } \\
\text { and its client software (VMWare } \\
\text { vSphere Client). }\end{array}$ \\
\hline
\end{tabular}

*Remaining 4 weeks used for the final project.

\section{Final Project}

The final project requires the students to integrate and assimilate the knowledge that they have accumulated throughout the semester into a practical project. The project is divided into several practical areas, which are listed below:

- Setting up a virtual machine using VMWare ESXi and VMWare vSphere client (T6). If the class is small, students are additionally required to install and configure VMWare ESXi before being used. If the class is large, this responsibility falls on the instructor as there would be insufficient time for each student to perform this task.

- Installation and configuration of web server on the virtual machine. This task requires the students to install the operating system, as well as to install and configure the XAMPP software.

- The students are required to write PHP code to implement an inventory management system that keeps track of customer information and orders as well (T3). They are also required to create a company website based on what they have learned in T1.

- Finally, the students will have to install and configure the OwnCloud cloud storage system (T4).
- A report must be presented as a technical paper detailing the activities performed, as well as some literature review regarding the project.

\section{Software, Equipment and Infrastructure Requirements}

In order to deliver the subject effectively, several recommendations regarding the software, equipment, and infrastructure are presented in Table 4 based on our experience in teaching the subject.

TABLE IVV

SOFTWARE, EQUIPMENT \& INFRASTRUCTURE REQUIREMENTS FOR TEACHING THE SUBJECT

\begin{tabular}{|c|c|c|}
\hline Equipment & Description & $\begin{array}{l}\text { Used } \\
\text { During }\end{array}$ \\
\hline $\begin{array}{l}\text { Personal } \\
\text { Computer } \\
\text { (PC) }\end{array}$ & $\begin{array}{l}\text { Used in all practical laboratory } \\
\text { session and final project. The choice } \\
\text { of Operating System (OS) is relatively } \\
\text { open as the software used is generally } \\
\text { platform-neutral. For hardware, in } \\
\text { UiTM's implementation, the PCs } \\
\text { were equipped with Intel i5 Central } \\
\text { Processing Unit (CPU) with } 8 \text { GB of } \\
\text { Random Access Memory (RAM). }\end{array}$ & $\begin{array}{l}\text { All } \\
\text { tutorials } \\
\text { and } \\
\text { final } \\
\text { project. }\end{array}$ \\
\hline BOINC & $\begin{array}{l}\text { Used in } \mathrm{T} 2 \text { where students can learn } \\
\text { to install and configure the BOINC } \\
\text { client and contribute to a project of } \\
\text { their choosing. }\end{array}$ & $\mathrm{T} 2$ \\
\hline $\begin{array}{l}\text { XAMPP } \\
\text { Software }\end{array}$ & $\begin{array}{l}\text { XAMPP is a software package } \\
\text { containing several important services } \\
\text { typically used in web servers } \\
\text { (Apache, MySQL, File Transfer } \\
\text { Protocol (FTP) and email services). } \\
\text { The software is available at no cost. }\end{array}$ & $\begin{array}{l}\text { T3 } \\
\text { upwards } \\
\text { and } \\
\text { final } \\
\text { project. }\end{array}$ \\
\hline $\begin{array}{l}\text { Google } \\
\text { Account } \\
\text { (individual } \\
\text { account for } \\
\text { each } \\
\text { student) }\end{array}$ & $\begin{array}{l}\text { A Google account is required for the } \\
\text { students to experiment with the } \\
\text { various cloud-based features of } \\
\text { Google in Tutorial } 1 \text { such as Google } \\
\text { Drive and Google Sites. Students can } \\
\text { use their existing accounts if already } \\
\text { available. }\end{array}$ & $\begin{array}{l}\text { T1 and } \\
\text { also to } \\
\text { store } \\
\text { lecture } \\
\text { notes in } \\
\text { Google } \\
\text { Drive. }\end{array}$ \\
\hline $\begin{array}{l}\text { VMWare } \\
\text { Player or } \\
\text { VMWare } \\
\text { Workstation }\end{array}$ & $\begin{array}{l}\text { Virtualization software with type } 2 \\
\text { hypervisor. VMWare Player is } \\
\text { available with limited features at no } \\
\text { cost, while VMWare Workstation is } \\
\text { the paid version with full-fledged } \\
\text { features. An alternative to this } \\
\text { software is Oracle VirtualBox, which } \\
\text { also available at no cost. }\end{array}$ & $\begin{array}{l}\text { T3 to } \\
\text { T5. }\end{array}$ \\
\hline $\begin{array}{l}\text { VMWare } \\
\text { ESxi }\end{array}$ & $\begin{array}{l}\text { Enterprise virtualization software with } \\
\text { type } 2 \text { hypervisor. Accessible with } \\
\text { VMWare vSphere Client software. } \\
\text { ESXi is available as a fully-functional } \\
\text { trial for } 60 \text { days at no cost. }\end{array}$ & $\begin{array}{l}\text { T6 and } \\
\text { final } \\
\text { project. }\end{array}$ \\
\hline $\begin{array}{l}\text { ESXi } \\
\text { Server }\end{array}$ & $\begin{array}{l}\text { The minimum specifications to run } \\
\text { ESXi 6.0 are [15]: } \\
\text { - Minimum dual-core x64 } \\
\text { (CPU) } \\
\text { - } 8 \text { GB RAM } \\
\text { In our experience, a mid-level server } \\
\text { with the following specification was } \\
\text { used: } \\
\text { - Intel i7 } 3.0 \mathrm{GHz} \text { CPU } \\
\text { - } 12 \text { GB Random Access }\end{array}$ & $\begin{array}{l}\text { T6 and } \\
\text { final } \\
\text { project. }\end{array}$ \\
\hline
\end{tabular}




\begin{tabular}{|c|c|c|}
\hline & $\begin{array}{l}\text { Memory } \\
\text { - } 1.5 \text { TB Hard Disk Drive } \\
\text { (HDD) } \\
\text { This server was found to be suitable } \\
\text { for small classes ( } 10 \text { students or less, } \\
\text { simultaneous access to the server). } \\
\text { For mass lecture classes, it is } \\
\text { recommended that the students be } \\
\text { organized into groups for the final } \\
\text { project, as the performance of the } \\
\text { server was found to be significantly } \\
\text { reduced with too many simultaneous } \\
\text { accesses. }\end{array}$ & \\
\hline Network & $\begin{array}{l}\text { An excellent network connection is } \\
\text { extremely important as the tutorials } \\
\text { rely on a fast and stable connection to } \\
\text { remote servers over the intranet and } \\
\text { the internet. }\end{array}$ & $\begin{array}{l}\text { All } \\
\text { tutorials }\end{array}$ \\
\hline
\end{tabular}

\section{IV.CONCLUSION}

Cloud computing is a relatively new and emerging technology in the field of computer engineering [12]-[14]. It is imperative to prepare students with knowledge in cloud computing when they enter the workforce. The integration of the CompTIA Cloud+ into the ECE648 subject is detailed, with recommendations and guidelines for implementation in other universities.

\section{ACKNOWLEDGMENT}

The authors would like to thank Universiti Teknologi MARA (UiTM) Malaysia for the funding for this research (Grant number: 600-RMI/DANA 5/3/ARAS (4/2015)).

\section{REFERENCES}

[1] P. Mell and T. Grance, "The NIST definition of cloud computing," NIST Special Publication, vol. 145, pp. 1-7, Sep. 2011.

[2] M. Haghighat, S. Zonouz, and M. Abdel-Mottaleb, "CloudID: Trustworthy cloud-based and cross-enterprise biometric identification," Expert Systems with Applications, vol. 42, pp. 79057916, Nov. 2015.
[3] Cisco. (2016) Cisco global cloud index: Forecast and methodology, 2014-2019 white paper [Online]. Available: http://www.cisco.com/c/en/us/solutions/collateral/serviceprovider/global-cloud-index-gci/Cloud_Index_White_Paper.html

[4] G. I. A. Inc. (2016) Cloud computing services: A global strategy business report. [Online]. Available: http://www.strategyr.com/Cloud_Computing_Services_Market_Repo rt.asp

[5] I. Khalil. (2016) Course title: Cloud computing. [Online]. Available: http://www1.rmit.edu.au/courses/049803

[6] University of Technology Sydney. (2016) 42904 cloud computing and software as a service. [Online]. Available: http://handbook.uts.edu.au/subjects/details/42904.html

[7] M. Kechadi and University College Dublin. (2016) Cloud computing (COMP41110). [Online]. Available: https://sisweb.ucd.ie/usis/w_sm_web_inf_viewer_banner.show_mod ule?p_subj=COMP\&p_crse $=41110$

[8] Lim Kok Wing University. (2016) Bachelor of Computer Science (Hons) in Cloud Computing Technology. [Online]. Available: https://www.limkokwing.net/malaysia/academic/courses_details/bach elor_of_computer_science_hons_in_cloud_computing_technology

[9] CompTIA. (2016) CompTIA Cloud+. [Online]. Available: https://certification.comptia.org/certifications/cloud\#examdetails

[10] M. Yassin. (2016) Course notes: ECE648 special topics. [Online]. Available: https://sites.google.com/site/ihsanyassin2/course-notesece648-special-topics

[11] VMWare. (2016) VSphere documentation centre: ESXi hardware requirements. [Online]. Available: https://pubs.vmware.com/vsphere50/index.jsp?topic $=\% 2$ Fcom.vmware.vsphere.install.doc_50\%2FGUI D-DEB8086A-306B-4239-BF76-E354679202FC.html

[12] V. Chang, R. J. Walters, and G. B. Wills, "Organisational sustainability modelling-An emerging service and analytics model for evaluating Cloud Computing adoption with two case studies.,"International Journal of Information Management, vol. 36, pp. 167-179, Feb. 2016.

[13] I. M. Yassin, A. Zabidi, M. S. A. M. Ali, N. M. Tahir, H. A. Hassan, H. Z. Abidin, and Z. I. Rizman, "Binary particle swarm optimization structure selection of nonlinear autoregressive moving average with exogenous inputs (NARMAX) model of a flexible robot arm," International Journal on Advanced Science, Engineering and Information Technology, vol. 6, pp. 630-637, Oct. 2016.

[14] M. N. M. Nor, R. Jailani, N. M. Tahir, I. M. Yassin, Z. I. Rizman, and R. Hidayat, "EMG signals analysis of BF and RF muscles in autism spectrum disorder (ASD) during walking," International Journal on Advanced Science, Engineering and Information Technology, vol. 6, pp. 793-798, Oct. 2016. 